\title{
Antipsykotika kan gi økt risiko for venøs tromboembolisme
}

\section{$\emptyset k t$ risiko for venøs tromboembo- \\ lisme var mest markant hos nye}

brukere av antipsykotiske legemidler

og ved bruk av atypiske antipsykotika.

Studier har vist at antipsykotiske legemidler gir økt risiko for venøs tromboembolisme, men studiene har vært små eller ikke omfattet nye atypiske antipsykotika. Nå har forskere undersøkt risikoen for venøs tromboembolisme ved bruk av ulike typer antipsykotiske legemidler i det britiske pasientregisteret til allmennleger (1).

En nøstet pasient-kontroll-studie omfattet 15975 med dyp venetrombose og $9557 \mathrm{med}$ lungeemboli og 89491 kontrollpersoner. Pasienter som var blitt forskrevet antipsykotika i de siste 24 månedene, hadde $32 \%$ større risiko for venøs tromboembolisme enn ikke-brukere (OR 1,32; $95 \% \mathrm{KI} 1,23-1,42)$. De som hadde startet med et nytt antipsykotikum i løpet av de siste tre månedene, hadde dobbelt så høy risiko $(1,97 ; 1,66-2,33)$. Risikoen var større med atypiske legemidler enn med konvensjonelle.

- Studien viser hvor viktig det er å følge opp somatisk helse hos pasienter som behandles med antipsykotika, og man må være bevisst økt risiko for venetrombose, sier professor Ole A. Andreassen ved Oslo universitetssykehus.

- Flere mindre studier har antydet samme tendens tidligere, men dette store materialet gir meget overbevisende resultater. Det må imidlertid gjøres nye kliniske studier hvor flere aspekter blir studert, før man ev. endrer forskrivningspraksis. Det er viktig å merke seg at $98 \%$ ble behandlet for svim- melhet, oppkast og kvalme og ikke for alvorlig psykisk sykdom. Forskerne gjorde flere forbehold hva gjelder andre risikofaktorer for venøs tromboembolisme, som ikke er tatt med i studien. Selv om risikoøkningen var høysignifikant, var den relativt beskjeden; 4 per 10000 personår, sier Andreassen.

\section{Trine B. Haugen}

trine.b.haugen@hf.hio.no

Tidsskriftet

\section{Litteratur}

- Parker C, Coupland C, Hippisley-Cox J. Antipsychotic drugs and risk of venous thromboembolism: nested case-control study. BMJ 2010; 341 . c4245.

\section{Salmonella typhimurium bruker et vertscelleenzym}

$\mathrm{S}$ typhimurium skiller ut et salmonellainvasjonsprotein, SipA, som hjelper til med å invadere epitelceller i tarmen. Amerikanske og skotske forskere har nå studert virkningsmekansimen til dette proteinet (Science 2010; 330: 390-3).

Under infeksjonen aktiverer SipA vertscelleenzymet kaspase-3. Kaspase-3 kløyver SipA ved et spesifikt gjenkjennelsessete. Det fører til danning av to funksjonelle domener som er nødvendig for patogenese. Den ene virulente effektoren stimulerer aktinpolymeriseringen, som letter bakteriens inntrengning i cellen, den andre induserer inflammasjon. En punktmutasjon i kaspasemotivet førte til tap av virulens i en musemodell. Kaspase-3-prosessering kan representere en felles vert-patogen-interaksjonsstrategi.

\section{Kokainbelønning i hjernen}

Nucleus accumbulens (NAc) er nøkkelmediator i kokainbelønningen, og aktivering av både dopamin D1-reseptorer og D2-reseptorer bidrar til effekten. Nå er rollene til de to populasjonene NAc-projeksjonsnevroner, som uttrykker D1 versus D2, i kokainbelønning studert (Science 2010; 330: 385-90).

I en musemodell ble de to subtypene av nevroner manipulert slik at fyring av hver celletype kunne kontrolleres. Aktivering av D2-positive nevroner førte til suppresjon av kokainbelønning, motsatt effekt ble observert for de D1-positive. Ved kokainavhengighet kan det være ubalanse nevronene imellom - overaktiv D1-signalering og redusert D2-aktivitet. Kunnskapen kan bidra til utvikling av behandling for avhengighet.

\section{Pipe- og sigarettrøyking i samme fareklasse}

\section{Piperøyking er like farlig som siga- rettrøyking, ifølge en stor norsk undersøkelse.}

Studien bygger på de store hjerte- og karundersøkelsene som i 1970- og 80-årene ble gjennomført i Finnmark, Sogn og Fjordane og Oppland, og omfattet personer i alderen 20-49 år. Undersøkelsene ble gjentatt med flere års intervall (1). Fremmøtet var nær $90 \%$. Dette er den fjerde artikkelen om røyking skrevet av Aage Tverdal og Kjell Bjartveit basert på data fra disse fylkesundersøkelsene (2).

I den nye studien konsentrerte forskerne seg om menn med stødige vaner, dvs. de som var rene pipe- eller sigarettrøykere, eller aldrirøykere, ved begge undersøkelsene. Grupper som kunne påvirke resultatene, ble ekskludert, f.eks. eksrøykere og sigarrøykere, og personer med tidligere hjerte- og karsykdommer og diabetes.

Mellom pipe- og sigarettrøykere med samme daglige forbruk var det ingen signifikant forskjell i dødelighet av alle årsaker, og ingen eller bare mindre forskjell i dødelighet av spesifiserte røykerelaterte sykdommer. Stødige piperøykere med det laveste konsum ( $<1$ pakke per uke) hadde en relativ dødsrisiko av alle årsaker på 1,79 (95\% KI 1,20-2,67) sammenliknet med stødige aldrirøykere. Resultatene ble justert for en serie andre risikofaktorer som ble registrert ved frem-

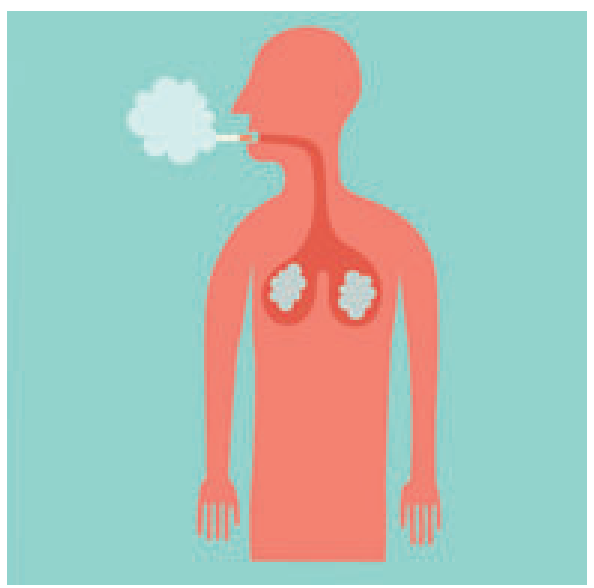

Illustrasjon Istockphoto

møtet. Det var heller ingen signifikant forskjell mellom pipe- og sigarettrøykere i overlevelse. Rene sigarettrøykere som ved det andre fremmøtet hadde skiftet til ren piperøyking, hadde ikke signifikant lavere dødsrisiko enn menn som fortsatte som rene sigarettrøykere.

\section{Erlend Hem}

erlend.hem@medisin.uio.no

Tidsskriftet

\section{Litteratur}

1. Tverdal A, Bjartveit K. Health consequences of pipe versus cigarette smoking. Tob Control 2010, doi: 10.1136/tc. 2010.036780 .

2. Hem E. Godt nytt for eksrøykere. Tidsskr Nor Legeforen 2009; 129: 1721 